С.В. Орєхов, О.В. Лезік, С.І. Корсунов, Б.К. Примоченко

Харківський начіональний університет Повітряних Сил ім. I. Кожедуба, Харків

\title{
АВІАЦІЙНА РАКЕТА АGМ-65 „МЕЙВЕРИК” ДОСВІД Ї̈ ЗАСТОСУВАННЯ ТА ОЦІНКА ЯК ЦІЛІ ДЛЯ ПІДРОЗДІЛІВ ПРОТИПОВІТРЯНОЇ ОБОРОНИ сухопУТних ВІйськ
}

В роботі проаналізовано досвід бойового застосування авіаційної ракети загального призначення (АРЗП) АGM-65 „Мейверик” класу „,повітря-поверхня”. Проведена очінка характеристик АРЗП АGM-65 „Мейверик” як иілі для військ ППО СВ. Наведені ї̈ розрахункові діаграми зворотного вторинного випромінювання (ДЗВВ) в сантиметровому діапазоні довжин хвиль. Дані положення можуть бути використані для підвищення ефективності навчання курсантів факультету та тих, щзо навчаються на курсах підвищення кваліфікації, вдосконалення навчального процесу підготовки спеціалістів факультету, а також якості підготовки спеиіалістів за фахом.

Ключові слова: ракети класу „,овітря-поверхня”, ППО СB, AGM-65 „Мейверик”, ЕПР, діаграми зворотнього вторинного випромінювання.

\section{Вступ}

Постановка проблеми. В теперішній час постійно зростає роль авіаційної високоточної зброї в ході локальних війн і конфліктів сучасності. За поглядами провідних військових фахівців, засоби повітряного нападу (ЗПН) озброєні високоточною зброєю, зокрема ракетами класу „повітря-поверхня”, $\epsilon$ основною ударною силою в сучасних війнах [1-7].

Ударні літаки, вертольоти та безпілотні літальні апарати озброєні авіаційними ракетами різного призначення (протирадіолокаційними, загального призначення, протитанковими керованими ракетами) будуть широко використовуватися як при рішенні повітряним противником задачі завоювання переваги в повітрі на початку активних бойових дій (війн та конфліктів), так і при рішенні завдань ізоляції району бойових дій (ізоляції поля бою) та безпосередньої авіаційної підтримки підрозділів і частин сухопутних військ на полі бою [1-5].

Розвиток керованої авіаційної ракетної ударної зброї та тактики ऑï застосування показує, що при нанесенні ударів такою зброєю носії в зону ураження зенітних комплексів (ближньої дії та малої дальності) заходять дуже на короткий час, або зовсім не заходять, внаслідок чого цілями для ураження зенітниками є вже не носії зброї, а безпосередньо ударні ракети. Тобто в умовах сьогодення, особливо актуальною та гострою для зенітних підрозділів $є$ проблема забезпечення ефективного та стійкого функціонування системи зенітного ракетноартилерійського прикриття військ та об'єктів в умовах вогневого впливу противника, як по об'єктах прикриття, так і по зенітних підрозділах, ракетною зброєю. Одним з заходів, спрямованих на рішення цієї проблеми є включення в склад угрупувань ППО ефективних засобів вогневого ураження ударних компонентів високоточної зброї противника, зокрема авіаційних ракет загального призначення (АРЗП), в ближній зоні [1-4].

Аналіз останніх досліджень і публікацій. У роботах [1-15] наголошується на зростанні ролі високоточної зброї в сучасних війнах та робиться висновок про велике різноманіття цілей для зенітних підрозділів. Відмічається що при організації ППО об'єктів та угрупувань військ, вона повинна бути не тільки протилітаковою, противертолітною, а і протиракетною. Але в проаналізованій літературі, відсутні систематизовані дані про авіаційні ракети класу „повітря-поверхня”, як цілі для зенітних підрозділів військ ППО СВ. 3 метою часткового усунення цього недоліку i пропонуються матеріали даної статті.

В якості об'єкта дослідження, в даній статті, була обрана АРЗП АGM-65 „Мейверик”, як яскравий представник свого класу ракет, що широко розповсюджений по всьому світу, в теперішній час експлуатується більше ніж в 30 країнах світу, і по оцінці військових фахівців буде стояти на озброєнні до 2030-2035 років [1-4].

Мета статті є аналіз досвіду та тактики застосування АРЗП АGM-65 “Мейверик” та оцінка iï як цілі для зенітних підрозділів військ ППО СВ.

\section{Виклад основного матеріалу}

Керована авіаційна ракета AGM-65 „Мейверик” призначена для оперативного нанесення високоточних ударів по військах і об'єктах тилу против- 
ника. Ракета дозволяє знищувати добре броньовані, захищені цілі (в тому числі і рухомі) в складних умовах. „Мейверик” має більш ніж десяти модифікацій з різними типами бойових частин та головок самонаведення (ГСН). Під час виробництва було зроблено більше ніж 70 тисяч ракет даного типу різних модифікацій. Всі варіанти АРЗП AGM-65 „Мейверик” мають однакову компоновку, зібрані по нормальній аеродинамічній схемі та оснащені 2-х режимним твердопаливним двигуном. Тяга двигуна в стартовому режимі - 4540 кгс, в маршовому - 990 кгс. Час роботи двигуна 3,5 с $[1-4]$.

Вага АРЗП АGM-65 „Мейверик” складає від 209 до 304 кг, в залежності від моделі та маси бойової частини. Максимальна дальність стрільби до 30 км, середня швидкість польоту ракети 0,93 М (1 150 км/год). Система наведення ракети: телевізійна, тепловізійна, лазерна чи комбінована в залежності від моделі ГСН. Точність наведення, КІВ: до 1,5 м. Модифікації АРЗП АGM-65 „Мейверик”, типи ГСН та бойових частин наведено в табл. 1.

Таблиця 1

Модифікації АРЗП АGM-65 „Мейверик”

\begin{tabular}{|c|c|c|}
\hline $\begin{array}{c}\text { Модифікацї } \\
\text { АРЗП АGM-65 }\end{array}$ & $\begin{array}{c}\text { Головка самонаве- } \\
\text { дення }(\text { ГСН })\end{array}$ & $\begin{array}{l}\text { Бойова } \\
\text { частина }\end{array}$ \\
\hline $\mathrm{A}, \mathrm{B}, \mathrm{H}$ & телевізійна & кумулятивна \\
\hline E, E2 & $\begin{array}{c}\text { напівактивна } \\
\text { лазерна }\end{array}$ & $\begin{array}{c}\text { осколково- } \\
\text { фугасна }\end{array}$ \\
\hline $\mathrm{D}$ & тепловізійна & кумулятивна \\
\hline $\mathrm{F}, \mathrm{F} 2, \mathrm{G}, \mathrm{G} 2$ & тепловізійна & $\begin{array}{c}\text { осколково- } \\
\text { фугасна }\end{array}$ \\
\hline $\mathrm{J}, \mathrm{JX}, \mathrm{K}$ & $\begin{array}{c}\text { комбінована, } \\
\text { трьох діапазонна } \\
\text { (на приладах } 3 \\
\text { зарядовим } \\
\text { зв’язком) }\end{array}$ & $\begin{array}{c}\text { осколково- } \\
\text { фугасна }\end{array}$ \\
\hline
\end{tabular}

Джерело: розроблено авторами за даними [1-4].

Необхідно відмітити, що в усіх модифікаціях АРЗП АGM-65 „Мейверик” реалізовано принцип „пустив-забув”, тобто екіпаж носія в наведенні ракети після її пуску не приймає жодної участі.

В якості носіїв даної ракети можуть використовуватися винищувачі-бомбардувальники, штурмовики, вертольоти різноманітного призначення, літаки РЕБ та безпілотні літальні апарати. Найбільш розповсюдженими носіями АРЗП АGM-65 „Мейверик” є: F-16, F-15, F/A-18, F-4, JAS 39, AV-8B та інші. Цікавий факт, в Малайзії в якості одного з можливих носіїв даної ракети використовують модернізований МиГ-29Н.

Найбільш масоване застосування ракет „Мейверик” було відмічено в ході операції „Буря в пустелі” - Ірак, 1991 рік. По різноманітних цілях було випущено більше ніж 5000 ракет. Середня бойова ефективність застосування ракети склала 0,6-0,7 при рішенні задачі безпосередньої авіаційної підтримки підрозділів сухопутних військ та 0,8-0,9 при рішенні задачі ізоляції району бойових дій (поля бою) в залежності від умов застосування та модифікації ракети.

Під час операції „Свобода Іраку”, що проводилася в березні-квітні 2003 року була застосована удосконалена керована ракета „Мейверик” AGM65G2 з тепловізійною ГСН, що дозволяє виявляти ціль і здійснювати іiі захват, як до так і після пуску ракети. Удари даними ракетами успішно наносились як по бронеоб'єктах, колонах військ, командних пунктах, укріплених районах, так і по складах, мостах та інших об'єктах тилу угрупування військ противника. Всього, під час проведення операції, було використано більш ніж 900 ракет. Ефективність бойового застосування, даної модифікації ракети, склала, за висновками військових фахівців - 0,97. У попередніх модифікацій ракет „Мейверік” цей показник не перевищував 0,9 [1-2].

Крім того, під час операції „Свобода Іраку”, силами коаліції широко застосовувалась АРЗП AGM-65E та E2, для підсилення безпосередньої вогневої підтримки підрозділів сухопутних військ. В ракеті AGM-65E(E2) використовується напівактивна лазерна ГСН, вона працює при „підсвітці” обраної цілі з землі або з повітря. Дана ракета призначена для ураження броньованих та захищених наземних цілей (в тому числі і рухомих), вдень і вночі, незалежно від умов погоди. Бойова частина (БЧ) осколково-фугасна, вагою 136 кг. Конструкція корпусу БЧ виключає іiі рикошет, а підрив здійснюється 3 запізненням, яке обирається в залежності від типу цілі. Носій ракети, при підльоті до району розташування цілі, здійснює пошук відбитого від неї лазерного кодованого променя. При виявленні цілі ГСН ракети захоплює та відслідковує її (на дальності до 18 км) без участі екіпажу. Дальність пуску не залежить від розміру цілі, а визначається лише тільки потужністю відбитого від неї сигналу. Військовими фахівцями відмічається, що використання напівактивної лазерної ГСН збільшує можливості ракети щодо поразки цілей, які швидко рухаються та маневрують.

Аналіз застосування АРЗП АGM-65 в воєнних конфліктах та війнах сучасності дозволяє зробити висновок, що вибір тактики нанесення ударів по цілях з використанням керованих ракет „Мейверик” залежить від типу цілі, умов бойового застосування авіації, кількості ударних літаків та протидії з боку ППО противника. Так, при виконанні атаки одиночним літаком або парою, політ до цілі проводиться на гранично малих висотах, з огинанням рельєфу місцевості, в режимі повного радіомовчання. При цьо- 
му літак виводиться в точку з якої ціль може бути гарантовано виявлена бортовими засобами. Носій, при вході в зону виявлення, здійснює пошук цілі за допомогою бортових засобів або візуально, або маневруючи літаком в горизонтальній площині проглядає район розташування цілі за допомогою ГСН ракети. Пуск ракет може проводитися залпом по одній цілі або атака може бути повторена з іншого напрямку. Типовим маневром літака при виході 3 атаки $\epsilon-$ розворот зі зниженням.

В зв'язку 3 високою бойовою ефективністю AРЗП AGM-65, удар по цілям, як правило наносять, пара або ланка літаків озброєних цими типами ракет. Якщо ціль точкова iї атакують з бойового порядку “в колону” послідовно наносячи по ній удари або перед підходом до цілі проводиться розпуск групи і ціль атакують з різних сторін, що дезорієнтує сили та засоби ППО противника. При атаці протяжної або площадної цілі літаки в заданому районі розмикаються по фронту, що дозволяє кожному екіпажу обирати свою ціль та зосередитися на прицілюванні. Такі дії знижують небезпеку зіткнення в бою зі своїми літаками та ускладнюють дії засобів ППО противника.

Атака цілей, керованою зброєю, в одному районі більш великими підрозділами ніж ланка, як правило, проводиться з різних напрямків та з невеликим часовим інтервалом. Необхідно відмітити, що дії ударних груп активно прикриваються завадами та діями відволікаючих груп, з малих і середніх висот та в зону поразки зенітних комплексів ближньої дії та малої дальності практично не входять.

Відмітимо, що у всіх випадках бойового застосування АРЗП екіпажі носіїв прагнуть застосувати зброю з максимально можливих відстаней від цілі 3 метою зменшити час перебування в зонах поразки зенітних засобів або зовсім в них не заходити. Тобто, ціллю для зенітних підрозділів стає не носій ракетної зброї, а сама ракета в польоті. В зв'язку з цим стає задача, оцінити АРЗП АGM-65 „Мейверик” (типова та розповсюджена АРЗП), як ціль для зенітних підрозділів. Тобто нам необхідно проаналізувати основні показники бойових властивостей даної ракети, а саме: швидкість польоту, діапазон висот бойового застосування, можливі дальності бойового застосування, маневреність, застосування засобів РЕБ та ефективну поверхню розсіювання (ЕПР) ракети. Проведений аналіз дозволяє зробити наступні висновки, керована ракета „Мейверик” рухається 3 середньою швидкістю польоту біля $300 \mathrm{~m} / \mathrm{c}$, але в зв'язку з тим, що іiі двигун працює лише 3,5 с, іiі швидкість на кінцевому етапі наведення буде суттєво залежати від дальності їі пуску по цілі. Так при пуску з максимально можливих дальностей застосування іï швидкість на кінцевій ділянці наведення буде в районі 200 м/с. Максимальною дальністю пуску АРЗП АGM-65 „Мейверик” вважається - 2030 км, в залежності від її модифікації, а ефективною дальністю застосування в умовах реальних бойових дій, військові фахівці вважають 6-17 км, в залежності від умов стрільби. Відмітимо, що ракети з телевізійними ГСН застосовуються переважно в умовах доброї видимості, а 3 тепловізійними та лазерними ГСН в любий час доби. Фахівці вважають, що ідеальними умовами для застосування ракет „Мейверік” (для всіх типів ГСН) є: денне світло, видимість до 20 км, при цьому сонце повинне „підсвітлювати” ціль і одночасно маскувати літак (носії повинні заходити зі сторони сонця) [1-4].

Керована ракети „Мейверик” на початковому відрізку траєкторії польоту рухається за допомогою інерційної системи наведення, а потім переходить на самоуправління від ГСН. Траєкторії польоту ракет до цілі близькі до параболічних чи квазіпрямолінійних, все залежить від висоти носія, його швидкості та дальності пуску ракети. Ракета в польоті не маневрує, тобто траєкторію свого руху не змінює. Час перебування ракети в польоті залежить від дальності пуску і складає: до 10-15 с при пуску з дальності 5 км та до 75-80 с. - 3 дальності 25 км. До можливих висот застосування даної ракет слід віднести: гранично малі, малі, середні і частково великі висоти. Тобто для підрозділів військ ППО СВ дана ракета є всевисотною. Відмітимо, що АРЗП АGM-65 „Мейверик” засобами РЕБ не обладнані, але при їх пусках, носії даних ракет можуть активно прикриватися завадами в радіолокаційних діапазонах довжин хвиль, що не впливає на роботу ГСН ракет бо вони працюють в інших частотних діапазонах.

На рис. 1 надано результати математичного моделювання діаграми зворотного вторинного випромінювання (ДЗВВ - залежність ЕПР ракети (в дБ) від кута іiі опромінення) АРЗП АGM-65 „Мейверик”, що отримані шляхом математичного моделювання за допомогою методики викладеної в [1619]. ДЗВВ показує залежність інтенсивності розсіяного досліджуваним об'єктом поля від його кутового положення відносно суміщеної приймальнопередавальної антени. Поняття ДЗВВ функціонально пов'язане з основною величиною, що характеризує властивості відбиття будь-якої радіолокаційної цілі, їі ЕПР. При певних допущеннях можна сказати, що ДЗВВ цілі є залежність ЕПР об'єкту від його кутового положення відносно приймальнопередавальної антени. Під ЕПР цілі $\sigma$ прийнято розуміти [20-21]:

$$
\sigma=\lim _{R \rightarrow \infty} 4 \pi R^{2} \frac{\left|\vec{p}^{n p} \vec{E}^{p a c}\right|^{2}}{\left|\vec{p} \vec{E}^{0}\right|^{2}},
$$

де $\vec{p}$-орти поляризації приймальної і передавальної антен;

$R$ - відстань від цілі до приймача; 
$\vec{E}^{\text {pac }}$ - вектор електричної напруженості поля, розсіяного об'єктом в напрямі на приймальну антену;

$\vec{E}^{0}$ - вектор електричної напруженості падаючої плоскої гармонійної ЕMX, тієї, що розповсюджується $з$ точки спостереження.

Сектор $270^{\circ}-90^{\circ}$ відповідає передній напівсфері ракети, а сектор $90^{\circ}-270^{\circ}$ відповідає їі задній напівсфері. Математичне моделювання проводилося при наступних умовах: довжина хвилі $\lambda=0,06$ м; кут розносу передавача та приймача дорівнює $0^{0}$ (моностатичний випадок).

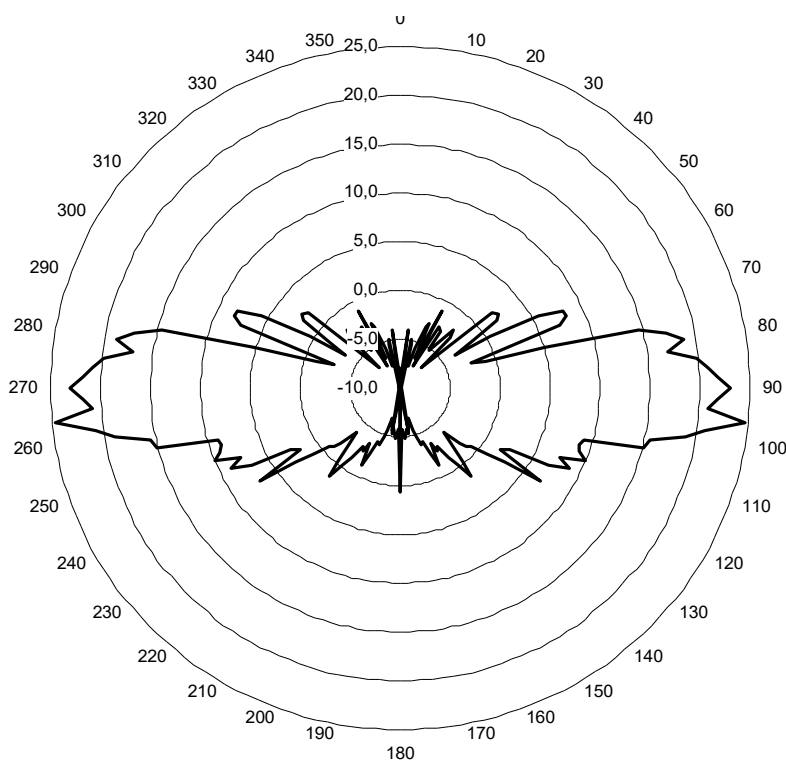

Рис. 1. ДЗВВ АРЗП АGM-65 „Мейверик” Джерело: розроблено авторами.
Аналіз ДЗВВ ракет AGM-65 „Мейверик” показує, що ії ЕПР, з передньої напівсфери в секторі $315^{0}$ - $45^{0}$, складає соті та десяті м².

Але враховуючи те, що підрозділи ППО, будуть розташовані біля об'єктів, по яким будуть наноситися удари даними ракетами, їх РЛС, найбільш імовірно, будуть спостерігати AGM-65 „Мейверик” 3 ракурсів зондування $350^{\circ}-10^{\circ}$. Середня ЕПР ракети в цьому діапазоні кутів зондування дорівнює $0,04-0,09 \mathrm{~m}^{2}$.

\section{Висновки}

Таким чином, оцінюючи АРЗП АGM-65 „Мейверик”, як ціль для зенітних підрозділів ВППО СВ, необхідно зробити наступні висновки.

Ціль складна, з малим часом перебування в зонах поразки зенітних засобів (десятки секунд), швидкістю 200-300 м/с та малою ЕПР - соті-одиниці десятих долей м², що ускладнює їх своєчасне виявлення розрахунками РЛС, а відповідно і ураження зенітними засобами.

Матеріали даної статті можуть бути використані фахівцями в галузі ППО військ, для аналізу тактики застосування АРЗП засобами повітряного нападу та побудови системи ППО військ та об'єктів, зокрема систем розвідки повітряного противника та зенітного ракетного артилерійського прикриття. Отримані ДЗВВ АРЗП АGM-65 „Мейверик” можуть бути використані фахівцями як доповнення до матеріалів викладених в [22].

\section{Список літератури}

1. Збройна боротьба у повітрі і космосі / М.О. Срмошин, С.П. Ярош, Є.І. Ряполов та ін. - Х.: ХНУПС, 2019. - 492 с.

2. Бойове застосування високоточних засобів пораження і особливості боротьби 3 ними / В.І. Ткаченко, С.П. Ярош, С.Б. Смірнов та ін.; за ред. В.І. Ткаченка. - Х.: ХУПС, 2016. - 272 с.

3. Довідник для офіцерів підрозділів військ протиповітряної оборони Сухопутних військ / М.І. Литвиненко, С.М. Піскунов, С.В. Орєхов та ін.; за ред. М.І. Литвиненка. -Х.: ХУПС, 2014. - 316 с.

4. Тактика підрозділів та частин військ протиповітряної оборони Сухопутних військ. Ч. І. Засоби повітряного нападу іноземних держав / В.І. Самоквіт, С.В. Орєхов, С.В. Ворошилов та ін.; за ред. С.В. Орєхова. - Х.: ХУПС, 2013. $284 \mathrm{c}$.

5. Дробаха Г.А. Розвиток тактики дій засобів повітряного нападу в локальних конфліктах XXI століття / Г.А. Дробаха, С.М. Піскунов, І.М. Тіхонов // Системи озброєння і військова техніка. - 2010. - № 1(21). - С. 6-10.

6. Смірнов О.О. Аналіз бойового застосування авіації в локальних війнах і збройних конфліктах другої половини XX - початку XXI сторіч / О.О. Смірнов, О.В. Блінов // Наука і техніка Повітряних Сил Збройних Сил України. - 2010. № 1(3). C. 67-75.

7. Корсунов С.І. Застосування засобів повітряного нападу провідних країн світу у збройних конфліктах і локальних війнах / С.І. Корсунов, Г.А. Левагін, В.О. Коротій // Збірник наукових праць Харківського національного університету Повітряних Сил. - 2016. - № 3(140). - С. 131-135.

8. Ярош С.П. Аналіз тактики бойового застосування крилатих ракет при нанесенні ударів по важливих державних об'єктах та угрупуваннях військ / С.П. Ярош, О.В. Рогуля // Збірник наукових праць Харківського національного університету Повітряних Сил. - 2019. - № 3(61). - С. 35-44. https://doi.org/10.30748/zhups.2019.61.06.

9. Аналіз застосування угрупування Повітряно-космічних сил Російської Федерації у Сірійській Арабській Республіці / С.І. Корсунов, О.В. Лезік, Ю.О. Галкін, М.І. Оборонов та ін. // Збірник наукових праць Харківського національного університету Повітряних Сил. - 2020. - № 4(66). - С. 7-17. https://doi.org/10.30748 / zhups.2020.66.01. 
10. Теорія і практика боротьби з малорозмірними низько літними цілями (оцінка можливостей, тенденції розвитку засобів протиповітряної оборони) : монографія / І.С. Романенко, О.М. Загорка, С.Г.Бутенко, О.В. Дайнега. - Ж.: Полісся, 2011. $-342 \mathrm{c}$.

11. Аналіз ведення бойових дій, тактики застосування ЗПН і використання нових інформаційних технологій у ході воєнного конфлікту в Лівії в 2011 році / С.П. Ярош // Наука і техніка Повітряних Сил Збройних Сил України. 2011. - № 2. - C. 19-25.

12. Ярош С.П. Обгрунтування організації зенітного ракетно-артилерійського прикриття угрупувань військ з застосуванням міжвидових мобільних вогневих підрозділів ППО СВ / С.П. Ярош, Б.М. Рябуха, Р.А. Соломонович // Наука і техніка Повітряних Сил Збройних Сил України. - 2020. - № 2(39). - С. 77-82. https://doi.org/10.30748/nitps.2020.39.09.

13. Шамко В.Є. Розвиток форм і способів застосування Повітряних Сил Збройних Сил України в сучасних умовах ведення збройної боротьби / В.С. Шамко, О.М. Жарик, В.В. Коваль // Наука і техніка Повітряних Сил Збройних Сил України. - 2018. - № 2(31). - C. 19-25. https://doi.org/10.30748/nitps.2018.31.01.

14. Степанов Г.С. Погляди щодо проблемних питань застосування Повітряних Сил в протиповітряній обороні / Г.С. Степанов, В.В. Камінський, М.А. Павленко // Наука і техніка Повітряних Сил Збройних Сил України. - 2018. № 1(30). - C. 18-23. https://doi.org/10.30748/nitps.2018.30.03.

15. Аналіз застосування БПЛА у вірмено-азербайджанському воєнному конфлікті та можливі шляхи боротьби 3 ними / А.Ф. Волков, О.В. Лезік, С.І. Корсунов, Г.А. Левагін, О.В. Яновський, К.В. Івахненко // Системи озброєння і військова техніка. - 2020. - № 4(64). - С. 7-17. https://doi.org/10.30748/soivt.2020.64.01.

16. Математичне моделювання діаграм зворотнього вторинного випромінювання протирадіолокаційних ракет в сантиметровому діапазоні довжин хвиль / С.В. Орєхов, А.Ф. Волков, О.В. Лезік, С.І. Корсунов // Системи озброєння і військова техніка. - 2019. - № 1(57). - С. 116-120. https://doi.org/10.30748/soivt.2019.57.16.

17. Mathematical Modeling of Diagrams of Reverse Secondary Radiation of Air-To-Ground Missiles for a Centimeter Wavelength Range / A. Volkov, S. Oriekhov, Y. Oboronov, M. Oboronov, V. Megelbey // 2020 IEEE Ukrainian Microwave Week. - Kharkiv, 21-25 September 2019. - P. 482-485.

18. Рассеяние электромагнитных волн воздушными и наземными радиолокационными объектами: монография / О.И. Сухаревский, В.А. Василец, С.В. Кукобко и др. - Х.: ХУПС, 2009. - 468 с.

19. Electromagnetic Wave Scattering by Aerial and Ground Radar Objects / S.V. Nechitaylo, V.M. Orlenko, O.I. Sukharevsky, V.A. Vasilets. - Boca Raton: SRC Press Taylor \& Francis Group, 2014. - 334 p.

20. Ширман Я.Д. Радиоэлектронные системы: Основы построения и теория / Я.Д. Ширман. - 2-е изд. - М.: Радиотехника, 2007. $-512 \mathrm{c}$.

21. Skolnik M.I. Radar Handbook / M.I. Skolnik. - 3d ed. - New York: McGraw-Hill, 2008. - 1348 p.

22. Сухаревський О.І. Довідник характеристик розсіювання повітряних та наземних радіолокаційних об'єктів / О.І. Сухаревський, В.О. Василець, С.В. Нечитайло. - Х.: ХНУПС, 2019. - 304 с.

\section{Відомості про авторів:}

\section{Орєхов Сергій Васильович}

кандидат технічних наук доцент доцент кафедри Харківського національного університету Повітряних Сил ім. І. Кожедуба, Харків, Україна https://orcid.org/0000-0001-6816-4720

\section{Лезік Олександр Віталійович}

кандидат військових наук доцент

доцент кафедри Харківського національного університету Повітряних Сил ім. І. Кожедуба, Харків, Україна https://orcid.org/0000-0002-7186-6683

\section{Корсунов Сергій Іванович}

старший викладач

Харківського національного університету

Повітряних Сил ім. І. Кожедуба,

Харків, Україна

https://orcid.org/0000-0002-5370-1375

\section{Information about the authors:}

\section{Serhii Oriekhov}

Candidate of Technical Sciences Associate Professor

Senior Lecturer of Ivan Kozhedub

Kharkiv National Air Force University,

Kharkiv, Ukraine

https://orcid.org/0000-0001-6816-4720

\section{Oleksandr Lezik}

Candidate of Military Sciences Associate Professor

Senior Lecturer of Ivan Kozhedub

Kharkiv National Air Force University,

Kharkiv, Ukraine

https://orcid.org/0000-0002-7186-6683

\section{Serhii Korsunov}

Senior Instructor

of Ivan Kozhedub Kharkiv

National Air Force University,

Kharkiv, Ukraine

https://orcid.org/0000-0002-5370-1375 
Примоченко Борис Костянтинович курсант

Харківського національного університету

Повітряних Сил ім. І. Кожедуба,

Харків, Україна

https://orcid.org/0000-0001-9446-6407

\author{
Boris Prymochenko \\ Cadet \\ of Ivan Kozhedub Kharkiv National \\ Air Force University, \\ Kharkiv, Ukraine \\ https://orcid.org/0000-0001-9446-6407
}

\title{
АВИАЦИОННАЯ РАКЕТА АGМ-65 „МЕЙВЕРИК”, ОПЫТ ЕЕ ПРИМЕНЕНИЯ И ОЦЕНКА КАК ЦЕЛИ ДЛЯ ПОДРАЗДЕЛЕНИЙ ПРОТИВОВОЗДУШНОЙ ОБОРОНЫ СУХОПУТНЫХ ВОЙСК
}

С.В. Орехов, А.В. Лезик, С.И. Корсунов, Б.К. Примоченко

В работе проанализирован опыт боевого применения авиачионной ракеты общего назначения (АРОН) AGM-65 „Мейверик” класса „, воздух-поверхность”. Проведена оценка характеристик АРОН AGM-65 „Мейверик” как иели для войск ПВО СВ. Приведены ее расчетные диаграммы обратного вторичного излучения (ДОВИ) в сантиметровом диапазоне длин волн. Данные положения могут быть использованы для повышения эффективности обучения курсантов факультета, слушателей курсов повышения квалификации, для усовершенствования учебного процесса подготовки специалистов факультета, а также качества подготовки специалистов по специальности.

Ключевые слова: ракета класса „воздух-земля”, ПВО СВ, АGM-65 „Мейверик”, ЭПР, диаграммы обратного вторичного излучения.

\section{AVIATION MISSILE AGM-65 “MAYVERIC", EXPERIENCE ITS APPLICATION AND EVALUATION AS GOALS FOR AIR DEFENSE UNITS OF THE GROUND FORCES}

\author{
S. Oriekhov, O. Lezik, S. Korsunov, B. Prymochenko
}

The paper analyzes the experience of combat use of the AGM-65 "Maverick" general purpose aviation missile of the airsurface class. The characteristics of the AGM-65 "Maverick" as a target for the SV air defense forces are evaluated. Its calculated diagrams of reverse secondary radiation in the centimeter wavelength range are given. Thus, we can conclude that the capabilities of the control system is most appropriate to assess from the standpoint of the implementation of the cycle. Since the control system consists of subsystems (controls, control points, ACS, communications and other special subsystems), to determine the capabilities of the control system as a whole it is necessary to be able to determine the capabilities of its subsystems. Currently, the role of high-precision aviation weapons in the course of local wars and conflicts of our time is constantly growing. According to leading military experts, air attack vehicles armed with high-precision weapons, in particular air-to-surface missiles are the main striking force in modern wars. The development of guided aviation missile strike weapons and tactics of its use shows that when striking with such weapons, carriers enter the zone of destruction of anti-aircraft systems (short-range and short-range) for a very short time, or do not enter at all, as a result of which the targets for hitting anti-aircraft gunners are no longer carriers of weapons, but directly attack missiles. That is, in the conditions of today, especially relevant and acute for antiaircraft units is the problem of ensuring the effective and stable functioning of the anti-aircraft missile and artillery cover system for troops and objects in the conditions of enemy fire influence, both on cover objects and on anti-aircraft units, missile weapons. One of the measures aimed at solving this problem is the inclusion in the air defense groups of effective means of Fire destruction of strike components of high-precision enemy weapons, in particular general-purpose aircraft missiles, in the near Zone. As the object of research, in this article, AGM-65 "Maverick" was chosen, as a bright representative of its class of missiles, widely distributed around the world, currently operated in more than 30 countries of the world, and according to military experts will be in service until 2030-2035. The purpose of the article is to analyze the experience and tactics of using the AGM-65 "Maverick" and evaluate it as a target for anti-aircraft units of the SV Air Defense Forces.

Keywords: air-to-ground missile, air defense SV, AGM-65 Maverick, EPR, reverse secondary radiation diagrams. 